\title{
Exchange Rate Regimes in the ASEAN: Would a Currency Union Outperform the Independent Managed Floating Regimes?
}

\author{
Ibrahima Sangaré ${ }^{+}$ \\ ${ }^{1}$ Central Bank of Luxembourg, Luxembourg
}

\begin{abstract}
This paper compares the macroeconomic and welfare performances of the currency union against those from the independent managed floating regime using a two open-country DSGE model with the foreign currency denomination of private debt. The model is calibrated on the average data from the five founding members of the ASEAN and the performance of regimes is assessed under the effects of supply and demand shocks. We find that the macroeconomic and welfare performances of the ASEAN economies under the independent managed floating regimes are comparable to those under a currency union. This is explained by the stability of the intra-regional nominal exchange rates arising from the similarity of policy rules under the independent managed floating regimes. Our findings suggest that the choice of exchange rate targeting regimes with coordinated policies for the ASEAN countries would be an effective way to move towards a currency union.
\end{abstract}

Keywords: ASEAN, monetary union, DSGE model, intra-regional exchange rate stability

JEL Classifications: E52, F33, F34, F41

Received 07 October 2019, Revised 20 September 2020, Accepted 09 December 2020

\section{Introduction}

The 1997 Asian financial crisis launched the debate on policies that would allow a greater stability of exchange rates across the Association of Southeast Asian Nations (henceforth ASEAN) countries. In particular, the advent of the euro in 1999 has made the idea of a common currency a particularly interesting option for the ASEAN countries (Bayoumi \& Mauro, 1999).

In this vein, many initiatives have been taken at the ASEAN level in favor of further economic integration to pave the way for the formation of an ASEAN currency area. These include the Chiang Mai initiative of May 2000 for establishing a network of bilateral swaps for countries in financial difficulties, the proposal of the establishment of an ASEAN Economic Community (AEC) during the Bali Concord II in 2003, the commitment in 2010 to make the ASEAN

\footnotetext{
+Comesponding Author: Ibrahima Sangaré

Ibrahima Sangaré, Central Bank of Luxembourg, 2 Boulevard Royal, Luxembourg, Email: ibrahima.sangare@bcl.lu

Disclaimer: This article should not be reported as representing the views of the BCL or the Eurosystem. The views expressed are those of the authors and may not be shared by other research staff or policymakers in the BCL or the Eurosystem.
} 
a free trade and tariff zone by 2015, and the endorsement of an ASEAN Banking Integration Framework (ABIF) in 2014, among others.

Furthermore, economic and monetary developments over the last two decades indicate an increase in trade dependence between the ASEAN member states (with total intra-ASEAN trade having grown by $191 \%$ from 2003 to 2019), a rise of intra-ASEAN foreign direct investments (which grew by $44 \%$ from 2010 to 2019) and some changes in exchange rate arrangements and monetary policy frameworks in the ASEAN area.1) In particular, the exchange rate arrangements of Thailand, Indonesia, Malaysia and Singapore have moved from managed floating regimes with no predetermined path for exchange rates in 2006 to stabilized arrangements for Singapore and Indonesia and floating arrangements for Malaysia and Thailand in 2008 (see IMF, 2006, 2008).

It is against this background that numerous papers have studied the feasibility of a currency union among the ASEAN countries (Zhang \& McAleer, 2004; Lee \& Azali, 2012; Ramayandi, 2005; Bayoumi et al., 2000; among others) based mostly on the following three interrelated optimum currency area (OCA) criteria from the seminal works of Mundell (1961), McKinnon (1963) and Kenen (1969): trade intensity, similarity of the shocks, and the degree of factor mobility. In particular, Eichengreen and Bayoumi (1999) developed an optimum currency index and showed that the value of that index for the ASEAN is not very different from what it was in Europe prior to the Maastricht Treaty. Binner et al. (2011) produce evidence that the five ASEAN countries and the ASEAN countries plus Taiwan meet the microeconomic criteria to form a common currency area. Engwerda et al. (2012) study the pros and cons of further economic integration of the ASEAN countries using the framework of linear quadratic differential games based on a stylized DSGE model. The authors find that there are substantial gains from cooperation of monetary authorities compared to forming a monetary union. Lee and Koh (2012)'s empirical results suggest that there exists a scope among ASEAN countries for potential monetary integration. Their finding of an increased symmetry of shocks among countries after the Asian Financial crisis indicates that the regional policy-coordinating effort after the crisis has put the region on the right track if monetary union is a desired goal. Finally, Tan (2016) provides some weak evidence of symmetric responses of the ASEAN economies to the common external shocks.

Another strand of the literature focuses on the similarity of exchange rate arrangements within the ASEAN region as an interim step towards an optimal currency area. For instance, Basnet et al. (2015) are interested in assessing the monetary policy synchronization among the founding members of the ASEAN and found that the real exchange rates of Malaysia, Philippines, Singapore, and Thailand share common cycles in the short term and have common trends in the long term, but the Indonesian currency does not share these relationships. Sethapramote

1) See Nguyen et al. (2016) for discussions on trade and foreign direct investment integration in ASEAN. 
(2015) also provides evidence of synchronization in exchange rates within ASEAN.

Unlike what is mainly addressed in the literature, the purpose of this work is not to assess whether the ASEAN region constitutes an optimum currency area or not. Rather, this paper theoretically compares the potential macroeconomic and welfare outcomes of a currency union in the ASEAN against those from an independent managed floating regime.

We first assume that the ASEAN countries satisfy the most popular criterion used in the literature for evaluating the optimum currency areas, namely the symmetry of shocks across countries. The symmetry of structural shocks among the ASEAN countries has been widely shown in the literature based on the Vector Autoregression (VAR) approach (see Lee \& Koh, 2012; Sethapramote, 2015; Balasubramaniam et al., 2012; Tan, 2016; Jean Louis et al., 2011). We present below some stylized facts that merely rely on the cross-country correlations of the macroeconomic variables as reflecting the symmetry of shocks within the ASEAN region. Contrary to the structural VAR approach that focuses on examining the shocks rather than observed economic variables by isolating the former from the latter, this approach assumes that symmetric shocks can translate into symmetric cross-country responses from macroeconomic variables that may then co-move and become interdependent. This choice also follows Sethapramote (2015), Balasubramaniam et al. (2012), Jean Louis et al. (2011) and Gauchan and Sharin (2018) who used both correlation and VAR approaches.

Table 1 presents the empirical cross-country correlations of three macroeconomic variables (i.e., total trade of goods, nominal GDP, and inflation) of the ASEAN-5 countries. We also calculate the correlations of these variables from each country with the average value of the ASEAN-5 economies. The quarterly data from 2000Q2 to 2019Q4 drawn from the ASEAN statistics and IMF international financial statistics are used. The correlation coefficients are positively significant in most cases. Total trade of goods displays the highest degree correlation ranging between 0.49 and 0.9 . The cross-country correlation of GDP growth shows some heterogeneities. It is relatively high and significant in the cases of Malaysia and Philippines with respect to Singapore while it is distinctly weak and non-significant for Indonesia, Malaysia and Philippines with respect to Thailand. The degrees of correlation of inflation are mostly significant and broadly homogenous. The highest degrees of correlation are recorded between the average ASEAN-5 and the individual countries irrespective of the considered variable (ranging between 0.6 and 0.9), with the exception of the weak and non-significant correlation between Indonesia's GDP growth and the average ASEAN-5's GDP growth. The correlation of Thailand's GDP growth and the ASEAN-5's GDP growth is weak but significant. Our results are in line with those in Sethapramote (2015). These empirical findings combined with those from the literature suggest an increasing symmetry of shocks and macroeconomic dependency within the ASEAN area. 
Table 1. Cross-Country Correlations of Some Macroeconomic Variables

\begin{tabular}{|c|c|c|c|c|c|c|}
\hline Trade growth & IND & MAL & PHI & SING & THA & ASEAN-5 \\
\hline IND & 1 & & & & & \\
\hline MAL & $0.7443 *$ & 1 & & & & \\
\hline PHI & $0.4941^{*}$ & $0.5960^{*}$ & 1 & & & \\
\hline SING & $0.7608 *$ & $0.8880^{*}$ & $0.6230 *$ & 1 & & \\
\hline THA & $0.6435^{*}$ & $0.6777^{*}$ & $0.5858^{*}$ & $0.7042 *$ & 1 & \\
\hline ASEAN-5 & $0.8622 *$ & $0.9072 *$ & $0.7660^{*}$ & $0.9233^{*}$ & $0.8330^{*}$ & 1 \\
\hline GDP growth & IND & MAL & PHI & SING & THA & ASEAN-5 \\
\hline IND & 1 & & & & & \\
\hline MAL & 0.1846 & 1 & & & & \\
\hline PHI & $-0.3374 *$ & $0.4535^{*}$ & 1 & & & \\
\hline SING & 0.0008 & $0.6158^{*}$ & $0.5196^{*}$ & 1 & & \\
\hline THA & -0.1796 & 0.0169 & -0.0023 & $0.3133^{*}$ & 1 & \\
\hline ASEAN-5 & 0.0315 & $0.7521 *$ & $0.8221 *$ & $0.8049 *$ & $0.2664 *$ & 1 \\
\hline Inflation & IND & MAL & PHI & SING & THA & ASEAN-5 \\
\hline IND & 1 & & & & & \\
\hline MAL & $0.2506^{*}$ & 1 & & & & \\
\hline PHI & $0.2404 *$ & $0.4852 *$ & 1 & & & \\
\hline SING & 0.1435 & $0.2957 *$ & $0.3576^{*}$ & 1 & & \\
\hline THA & -0.0097 & $0.3472 *$ & $0.4992 *$ & $0.3368^{*}$ & 1 & \\
\hline ASEAN-5 & $0.6443 *$ & $0.6761^{*}$ & $0.7303 *$ & $0.5815^{*}$ & $0.6070^{*}$ & 1 \\
\hline
\end{tabular}

Note. * statistically significant at $5 \%$ level. Quarter on quarter growth is used. Trade denotes imports of goods + exports of goods. IND=Indonesia, MAL=Malaysia, PHI=Philippines, SING=Singapore, THA=Thailand and ASEAN-5=Average of the five ASEAN founding members.

The idea behind the symmetry of shocks as a popular criterion of the optimum currency area is that the greater symmetry in underlying shocks among countries reduces the need of exchange rates to adjust the relative prices and makes those countries better candidates for a monetary union.

We finally ask whether participating countries in a possible currency union are better off when symmetric shocks occur compared to the situation of keeping their own independent managed floating regimes.

To this end, we build a two open-country DSGE model that features nominal and real rigidities, incomplete pass-through of exchange rates, financial frictions, and the foreign currency denomination of private debt. The model is calibrated on the five founding members of the ASEAN (Thailand, Indonesia, Malaysia, Singapore, and Philippines). We undertake a counterfactual simulation study by contrasting the potential macroeconomic and welfare effects of the shocks for individual countries under a currency union and an independent managed floating regime. The DSGE models are better suited for the counterfactual studies contrary to the empirical 
analyses widely used in the literature for addressing the issues of choice of exchange rate regimes. Supply and demand shocks are considered. We also investigate the role of coordination of independent policies in shaping our main results.

The contribution of this work is twofold. First, from the methodology perspective, unlike the literature mainly based on empirical analyses and focusing on the validity of the optimum currency area criteria, we compare the macroeconomic and welfare performances of countries under the monetary union and the independent floating regime using a two open-country DSGE model with a foreign currency denomination of debt. The second contribution of this work is to theoretically show that a particular independent exchange rate regime could replicate the macroeconomic and welfare performances of a currency union under certain conditions.

We find that, in terms of macroeconomic and welfare effects of supply and demand shocks, the independent managed floating regime provides a comparable advantage to a currency union for the ASEAN member countries. More specifically, output and welfare outcomes in the wake of supply and demand shocks are comparable under the two regimes. We also find that the similarity of the nominal effective exchange rate targeting policies and countries' trade-weighted baskets could produce the stability of the nominal bilateral exchange rates under the managed floating regimes in the ASEAN region. In other words, due to the stability of nominal bilateral exchange rates arising from implicit (or explicit) coordinated exchange rate targeting, the macroeconomic and welfare performances of the independent managed floating regimes are similar to those from a monetary union. This therefore suggests that when the ASEAN countries similarly target their nominal effective exchange rates via cooperation under the independent managed floating regimes, given the similarity among their trade partners, they would evolve in a sort of de facto currency union which would provide the same benefits as a lawfully constructed currency union (de jure currency union). These findings are in line with those from Engwerda et al. (2012). Nevertheless, it is worth mentioning that output and welfare outcomes are slightly higher under the monetary union than under the independent managed floating regime following a supply shock, while the same negligible advantage is found in favor of the independent regime when the considered shock is an external demand shock. These negligible differences between the monetary regimes come from the reaction function of the monetary authority under the independent managed floating regime, which reflects changes in the nominal exchange rate.

The rest of the paper is organized as follows: Section 2 lays out the two open-country general-equilibrium model. Section 3 presents the calibration of the model and the simulation study results. Section 4 concludes. 


\section{A Two Open-Region DSGE Model}

The regional economy consists of two countries of equal size, respectively labeled " $\mathrm{H}$ " as the home country, representing one part of the ASEAN region, and "RoR" as the foreign country that represents the other part of the region. They are open to the rest of the world (RoW) which is assumed to be fully exogenous.

The model is built upon the model from Sangare (2016) and features price stickiness, capital adjustment costs, incomplete pass-through of exchange rates introduced via the deviation from the law of one price, and financial frictions. In addition, the foreign currency denomination of private debt as one of the main features of the ASEAN economies is introduced in the model.

Each economy is populated by households, government, and three types of producers: entrepreneurs, capital producers, and retailers (domestic and imported goods retailers). There are monetary authorities that set the nominal risk-free interest rates for their countries, but in the case of forming a currency union there is a unified monetary policy that sets the unique nominal interest rate for both countries. Capital producers build new capital and sell it to the entrepreneurs. Entrepreneurs produce wholesale goods and sell them to domestic goods retailers. Domestic and imported goods retailers set nominal prices of final goods à la Calvo (1983). The government purchases aggregate public goods and finances its expenditures via lump-sum taxes.

\section{A. Households}

Each economy $i \in\{\mathrm{H}, \mathrm{RoR}\}$ is populated by a continuum of unit mass households. The representative household of country $i$ maximizes the following expected discounted sum of utilities:

$$
E_{t} \sum_{t=0}^{\infty} \beta^{t}\left(\frac{\left(C_{t}^{i}\right)^{1-\sigma}}{1-\sigma}-\frac{\left(N_{t}^{i}\right)^{1+\eta}}{1+\eta}\right)
$$

where $C_{t}^{i}$ is aggregate consumption and $N_{t}^{i}$ denotes the number of hours worked. $E_{t}$ is the conditional expectation operator. The parameters $0<\beta<1, \sigma>0$ and $\eta>0$ are, respectively, the subjective discount factor, the inverse intertemporal elasticity of substitution and the inverse of the Frisch elasticity of labor supply.

The household faces the following period-by-period budget constraint:

$$
P_{t}^{i} C_{t}^{i}+R_{t-1}^{i} B_{t-1}^{i}+R_{w, t-1} \Psi_{d, t-1}^{i}\left(d_{t-1}^{i}, Z_{t-1}^{i}\right) S_{2, t}^{i} D_{h, t-1}^{i}=W_{t}^{i} N_{t}^{i}+B_{t}^{i}+S_{2, t}^{i} D_{h, t}^{i}+\Lambda_{t}^{i}-\tau_{t}^{i}
$$


where $P_{t}^{i}$ is the consumer price index (CPI), $W_{t}^{i}$ the nominal wage, $B_{t}^{i}$ the nominal stock of domestic-currency debt and $D_{h, t}^{i}$ the nominal debt that is denominated in the rest of the world currency ${ }^{2}$. $R_{t}$ and $R_{w, t}$ are the domestic and the RoW gross nominal interest rate, respectively. $S_{2, t}^{i}$ is the bilateral nominal exchange rate between country $i \in\{\mathrm{H}, \mathrm{RoR}\}$ and the RoW (expressed in terms of units of domestic currency per unit of RoW currency) ${ }^{3)}, \tau_{t}^{i}$ denotes lump-sum taxes paid to the government, and $\Lambda_{t}^{i}$ the real profit from the monopolistic sector. Finally, $\Psi_{d, t}^{i}$ represents a risk premium that is a function of the economy's real aggregate level of net-foreign asset position in percentage of steady-state output, as follows:

$$
\Psi_{d, t}^{i}\left(d_{t}^{i}, Z_{t}^{i}\right)=\exp \left(\psi_{d}^{i}\left(\frac{S_{2, t}^{i} D_{t}^{i}}{Y P_{t}^{i}}\right)+Z_{t}^{i}\right)
$$

where $d_{t}^{i} \equiv \frac{S_{2, t}^{i} D_{t}^{i}}{Y P_{t}^{i}}$ is the real aggregate net-foreign asset position in percentage of steady-state output; $D_{t}^{i} \equiv D_{h, t}^{i}+D_{E, t}^{i}$ represents the total debt of each country4); $\psi_{d}^{i}>0$ is a measure of the elasticity of the risk premium with respect to the net-foreign asset (NFA) position. The variable $Z_{t}^{i}$ is an exogenous shock on risk premium defined by

$\log \left(Z_{t}^{i}\right)=\rho_{z} \log \left(Z_{t-1}^{i}\right)+e_{z, t}$ with $e_{z, t} \sim i . i . d\left(0, \sigma_{e_{z}}^{2}\right)$. The term $\Psi_{d, t}^{i}\left(d_{t}^{i}, Z_{t}^{i}\right)$ is assumed to be strictly increasing in $d_{t}^{i}$ and satisfies $\Psi_{d}^{i}(0,0)=1$. It captures imperfect integration in the international financial markets and ensures a well-defined steady-state for the model (Schmitt-Grohé and Uribe, 2003)5).

The representative household chooses the paths for $\left\{C_{t}^{i}, N_{t}^{i}, B_{t}^{i}, D_{t}^{i}\right\}_{0}^{\infty}$ in order to maximize (1) subject to the budget constraint in (2). The following optimality conditions hold:

$$
\frac{\left(N_{t}^{i}\right)^{\eta}}{\left(C_{t}^{i}\right)^{-\sigma}}=\frac{W_{t}^{i}}{P_{t}^{i}} \equiv w_{t}^{i}
$$

2) It is assumed that households can participate in both domestic and foreign currency denominated financial markets: they therefore can borrow in domestic currency and in foreign currency.

3) We define the bilateral nominal exchange rate within the region by $S_{1, t}^{i}$ such that, $S_{1, t}^{H}$ is the bilateral nominal exchange rate between $\mathrm{H}$ and $\mathrm{RoR}$, and $S_{1, t}^{R o R}=1 / S_{1, t}^{H}$ is the bilateral nominal exchange rate between RoR and H. In this case, the bilateral nominal exchange rate between the RoR and the RoW can be expressed as a function of $S_{1, t}^{H}$ and the bilateral nominal exchange rate between $\mathrm{H}$ and $\mathrm{RoW},\left(S_{2, t}^{H}\right)$, as $: S_{2, t}^{R o R}=S_{2, t}^{H} / S_{1, t}^{H}$. Notice that the formation of currency union implies that $S_{1, t}^{H}=S_{1, t}^{R o R}=1$.

4) $D_{E, t}^{i}$ is the entrepreneurs borrowing defined in subsection 2.3.1.

5) We assume the perfect integration in regional financial markets, i.e. there is no risk premium between the two countries of the region. Thus, the uncovered interest rate parity (UIP) holds within the region, but it does not hold between the economy $i \in\{\mathrm{H}, \mathrm{RoR}\}$ of the region and the rest of the world. 


$$
\begin{aligned}
& \left(C_{t}^{i}\right)^{-\sigma}=\beta R_{t}^{i} E_{t}\left(\left(C_{t+1}^{i}\right)^{-\sigma} \frac{P_{t}^{i}}{P_{t+1}^{i}}\right) \\
& \left(C_{t}^{i}\right)^{-\sigma}=\beta R_{w, t} \Psi_{d, t}^{i}\left(d_{t}^{i}, Z_{t}^{i}\right) E_{t}\left(\left(C_{t+1}^{i}\right)^{-\sigma} \frac{P_{t}^{i}}{P_{t+1}^{i}} \frac{S_{2, t+1}^{i}}{S_{2, t}^{i}}\right)
\end{aligned}
$$

The final good, $X_{t}^{i}$, is allocated to consumption, $C_{t}^{i}$, investment, $I_{t}^{i}$ and public spending, $G_{t}^{i}$. It is an aggregate function of goods produced in the domestic country, $X_{i, t}^{i}$, in the country $k, X_{k, t}^{i}$, and in the rest of the world (RoW), $X_{w, t}^{i}$ :

$$
X_{t}^{i}=\left[\left(1-a_{1}^{i}-a_{2}^{i}\right)^{\frac{1}{\theta}}\left(X_{i, t}^{i}\right)^{\frac{\theta-1}{\theta}}+\left(a_{1}^{i}\right)^{\frac{1}{\theta}}\left(X_{k, t}^{i}\right)^{\frac{\theta-1}{\theta}}+\left(a_{2}^{i}\right)^{\frac{1}{\theta}}\left(X_{w, t}^{i}\right)^{\frac{\theta-1}{\theta}}\right]^{\frac{\theta}{\theta-1}}
$$

for $X=\{C, I, G\} ; i, k \in\{\mathrm{H}, \mathrm{RoR}\}$ and $i \neq k$.

The parameters $\theta>1, a_{1}^{i}$, and $a_{2}^{i}$ are, respectively, the elasticity of substitution between the three types of goods, the share of imported goods from the country $k$, and the share of imported goods from the RoW. We suppose that these shares are reciprocally identical between countries $i \in\{\mathrm{H}, \mathrm{RoR}\}$ of the region and the rest of the world (RoW). Therefore, the fraction $\left(1-a_{1}^{i}-a_{2}^{i}\right)$ is the degree of home bias in consumption, investment, and public goods.

The price index (CPI) associated to (7) is given by:

$$
P_{t}^{i}=\left[\left(1-a_{1}^{i}-a_{2}^{i}\right)\left(P_{i, t}^{i}\right)^{1-\theta}+a_{1}^{i}\left(P_{k, t}^{i}\right)^{1-\theta}+a_{2}^{i}\left(P_{w, t}^{i}\right)^{1-\theta}\right]^{\frac{1}{1-\theta}}
$$

where $P_{i, t}^{i}, P_{k, t}^{i}$ and $P_{w, t}^{i}$ are, respectively, the domestic price of domestic goods, the domestic price of imported goods from the country $k$ and the domestic price of imported goods from the rest of the world (RoW).

Define $X_{i, t}^{i} \equiv\left(\int_{0}^{1} X_{i, t}^{i}(j)^{\frac{\chi-1}{\chi}} d_{j}\right)^{\frac{\chi}{\chi-1}}, X_{k, t}^{i} \equiv\left(\int_{0}^{1} X_{k, t}^{i}(j)^{\frac{\chi-1}{\chi}} d_{j}\right)^{\frac{\chi}{\chi-1}}$ and $X_{w, t}^{i} \equiv\left(\int_{0}^{1} X_{w, t}^{i}(j)^{\frac{\chi-1}{\chi}} d_{j}\right)^{\frac{\chi}{\chi-1}}$ as the composite aggregates of differentiated varieties produced domestically, in the foreign $(k)$ and the rest of the world, respectively, with $\chi$ being the elasticity of substitution between varieties of goods originating from the same country; $X_{i, t}^{i}(j), X_{k, t}^{i}(j)$ and $X_{w, t}^{i}(j)$ being a typical variety $j$ of domestic goods, imported goods from the foreign country $k$, and imported goods from the rest of the world (RoW), respectively. The corresponding prices are derived easily and are respectively given by: 


$$
P_{i, t}^{i}=\left(\int_{0}^{1} P_{i, t}^{i}(j)^{1-\chi} d_{j}\right)^{\frac{1}{1-\chi}}, P_{k, t}^{i=}\left(\int_{0}^{1} P_{k, t}^{i}(j)^{1-\chi} d_{j}\right)^{\frac{1}{1-\chi}}, P_{w, t}^{i=}\left(\int{ }_{0}^{1} P_{w, t}^{i}(j)^{1-\chi} d_{j}\right)^{\frac{1}{1-\chi}},
$$

where $P_{i, t}^{i}(j)$ (respectively $P_{k, t}^{i}(j)$ and $\left.P_{w, t}^{i}(j)\right)$ is the price of a typical variety $j$ produced in the domestic country (respectively imported prices from the country $k$ and the RoW).

The optimal domestic demands for domestic, foreign country $k$, and the rest of the world (RoW) goods are derived from the expenditure minimization6):

$$
\begin{aligned}
& X_{i, t}^{i}=\left(1-a_{1}^{i}-a_{2}^{i}\right)\left(\frac{P_{i, t}^{i}}{P_{t}^{i}}\right)^{-\theta} X_{t}^{i} \\
& X_{k, t}^{i}=a_{1}^{i}\left(\frac{P_{k, t}^{i}}{P_{t}^{i}}\right)^{-\theta} X_{t}^{i} \\
& X_{w, t}^{i}=a_{2}^{i}\left(\frac{P_{w, t}^{i}}{P_{t}^{i}}\right)^{-\theta} X_{t}^{i}
\end{aligned}
$$

$\forall i, k \in\{\mathrm{H}, \mathrm{RoR}\}$ and $i \neq k$.

\section{B. Open-economy relations}

This section outlines the key relations that describe the terms of trade, the real exchange rates, and the law of one price deviations. For each economy $i, k \in\{\mathrm{H}, \mathrm{R} \circ \mathrm{R}\}$ and $i \neq k$, we define the bilateral terms of trade as:

$$
\operatorname{TOT}_{k, t}^{i}=\frac{P_{k, t}^{i}}{P_{i, t}^{i}} \text { and } \operatorname{TOT}_{w, t}^{i}=\frac{P_{w, t}^{i}}{P_{i, t}^{i}}
$$

From (8), the terms of trade can be related to the CPI-DPI7) ratio as follows:

$$
\frac{P_{t}^{i}}{P_{i, t}^{i}}=\left[\left(1-a_{1}^{i}-a_{2}^{i}\right)+a_{1}^{i}\left(T O T_{k, t}^{i}\right)^{1-\theta}+a_{2}^{i}\left(T O T_{w, t}^{i}\right)^{1-\theta}\right]^{\frac{1}{1-\theta}}
$$

Assume that the law of one price (LOP) holds for the export sector, but there is incomplete

6) The optimization program is ${ }_{C_{i, t}^{i}}^{i}, C_{k, t}^{i}, C_{w, t}^{i}, C_{t}^{i} P_{i, t}^{i} C_{i, t}^{i}+P_{k, t}^{i} C_{k, t}^{i}+P_{w, t}^{i} C_{w, t}^{i}=P_{t}^{i} C_{t}^{i}$ subject to the following constraint: $C_{t}^{i}=\left[\left(1-a_{1}-a_{2}\right)^{\frac{1}{\theta}}\left(C_{i, t}^{i}\right)^{\frac{\theta-1}{\theta}}+\left(a_{1}\right)^{\frac{1}{\theta}}\left(C_{k, t}^{i}\right)^{\frac{\theta-1}{\theta}}+\left(a_{2}\right)^{\frac{1}{\theta}}\left(C_{w, t}^{i}\right)^{\frac{\theta-1}{\theta}}\right]^{\frac{\theta}{\theta-1}}$.

7) DPI: Domestic Price Index. 
pass-through of exchange rates for the import sector. This assumption is motivated by the existence of monopolistic domestic importers that practice local currency pricing (Devereux and Engel, 2001). This pricing practice can lead the price of the foreign goods in the domestic market to temporarily deviate from the producer price in the country of origin. The wedge between these two prices is called the law of one price gap (LOPG) and is bilaterally given by:

$$
L O P G_{k, t}^{i}=\frac{S_{1, t}^{i} P_{k, t}^{k}}{P_{k, t}^{i}} \text { and } L O P G_{w, t}^{i}=\frac{S_{2, t}^{i} P_{w, t}^{w}}{P_{w, t}^{i}}
$$

where $P_{k, t}^{k}$ and $P_{w, t}^{w}$ are domestic prices in country $k$ of the region and in the rest of the world (RoW). Similarly, we define the bilateral real exchange rates as follows:

$$
R E R_{k, t}^{i}=\frac{S_{1, t}^{i} P_{t}^{k}}{P_{t}^{i}} \text { and } R E R_{w, t}^{i}=\frac{S_{2, t}^{i} P_{t}^{w}}{P_{t}^{i}}
$$

Finally, one can express the effective terms of trade, the effective law of one price gap, and the real effective exchange rate, for each country $i \in\{\mathrm{H}, \mathrm{RoR}\}$ as 8 ):

$$
\begin{aligned}
& \operatorname{TOT}_{t}^{i}=\left(T O T_{k, t}^{i}\right)^{a_{1}^{i}}\left(T O T_{w, t}^{i}\right)^{a_{2}^{i}} \\
& L O P G_{t}^{i}=\left(L O P G_{k, t}^{i}\right)^{a_{1}^{i}}\left(L O P G_{w, t}^{i}\right)^{a_{2}^{i}} \\
& R E R_{t}^{i}=\left(R E R_{k, t}^{i}\right)^{a_{1}^{i}}\left(R E R_{w, t}^{i}\right)^{a_{2}^{i}}
\end{aligned}
$$

When the two regions $\{\mathrm{H}, \mathrm{RoR}\}$ decide to form a monetary union, we assume that they would have the same size and the real effective exchange rate for the union is therefore:

$$
R E R_{t}^{u}=\left(R E R_{t}^{H}\right)^{\frac{1}{2}}\left(R E R_{t}^{R o R}\right)^{\frac{1}{2}}=\left(R E R_{w, t}^{H}\right)^{\frac{a_{2}^{i}}{2}}\left(R E R_{w, t}^{R o R}\right)^{\frac{a_{2}^{i}}{2}}
$$

which can be written also in terms of the union's nominal exchange rate $\left(S_{t}\right)$ :

$$
R E R_{t}^{u}=\frac{S_{t} P_{t}^{w}}{P_{t}^{u}}
$$

8) The nominal effective exchange rate (NEER) for each country is $S_{t}^{i}=\left(S_{1, t}^{i}\right)^{a_{1}^{i}}\left(S_{2, t}^{i}\right)^{a_{2}^{i}}$. 
where $P_{t}^{u}$ and $P_{t}^{w}$ are the consumption price indexes (CPI) of the Monetary Union (the average of both national CPIs) and the rest of the world, respectively.

\section{Production sector}

\section{Entrepreneurs}

The financial friction at the level of entrepreneurs introduces the financial accelerator mechanism into the model. As in Bernanke et al. (1999), entrepreneurs manage a continuum of firms $j \in[0,1]$ that produces, by using $K_{t}^{i}$ units of capital and $N_{t}^{i}$ units of labor, wholesale (intermediate) goods in a perfectly competitive market according to the following technology:

$$
Y_{t}^{i}(j)=A_{t}^{i} K_{t}^{i}(j)^{\alpha} N_{t}^{i}(j)^{1-\alpha}
$$

where $A_{t}^{i}$ is a technological shock that is common to all firms and follows a stationary first-order autoregressive process: $\log \left(A_{t}^{i}\right)=\rho_{A} \log \left(A_{t-1}^{i}\right)+e_{A, t}$, with $e_{A, t} \sim i . i . d\left(0, \sigma_{e_{A}}^{2}\right) ; \alpha \in[0,1]$ is the share of capital in the production technology.

The representative firm maximizes its profit by choosing $K_{t}^{i}$ and $N_{t}^{i}$ subject to the production function (21). The first-order conditions for this optimization problem are:

$$
\begin{gathered}
w_{t}^{i}=(1-\alpha) m c_{t}^{i} \frac{Y_{t}^{i}}{N_{t}^{i}} \frac{P_{i, t}^{i}}{P_{t}^{i}} \\
m p c_{t}^{i}=\alpha m c_{t}^{i} \frac{Y_{t}^{i}}{K_{t}^{i}} \frac{P_{i, t}^{i}}{P_{t}^{i}}
\end{gathered}
$$

where $m c_{t}^{i}$ is the Lagrangian multiplier associated with the production function (21) and defines the real marginal cost; $w_{t}^{i}$ is the real wage; and $m p c_{t}^{i}$ is the real marginal productivity of capital.

Entrepreneurs are risk neutral and borrow from the rest of the world to finance the share of capital used in the production process. This indebtedness in the rest of the world currency characterizes the original sin phenomenon. As in Bernanke et al. (1999), to ensure that they never accumulate enough funds to fully self-finance their own activities, assume that they have a finite expected horizon. In each period $t$, entrepreneurs face a constant probability $(1-\nu)$ of leaving the economy. We follow Christensen and Dib (2008) in allowing newly entering entrepreneurs to inherit a fraction of the net worth of those firms which exit from the business. This assumption is made to ensure that new entrepreneurs start out with a positive net worth.

At the end of each period, entrepreneurs purchase capital, $K_{t+1}^{i}$, that will be used in the 
next period at the real price $q_{t}^{i}$. Thus, the total funding need of an entrepreneur to purchase capital is $q_{t}^{i} K_{t+1}^{i}$. The capital acquisition is financed partly by their net worth, $N W_{t+1}^{i}$, and by borrowing, $D_{E, t+1}^{i}=q_{t}^{i} K_{t+1}^{i}-N W_{t+1}^{i}$, from the RoW.

As demonstrated in Bernanke et al. (1999), the optimal financial contract between the borrower and the lender implies an external finance premium (the difference between the cost of external and internal finance), $\Psi_{E, t}^{i}(\bullet)$, that depends on the entrepreneur's leverage ratio (i.e., capital to net worth ratio).

The optimal condition is such that the entrepreneur's demand for capital satisfies the equality between the expected real return on capital and the expected marginal financing cost (i.e., gross premium for external finance plus the gross real interest rate on the borrowing) ${ }^{9}$ ):

$$
E_{t}\left(R_{K, t+1}^{i}\right)=E_{t}\left[R_{w, t} \Psi_{d, t}^{i}\left(d_{t}^{i}, Z_{t}^{i}\right) \Psi_{E, t+1}^{i}(\bullet) \frac{S_{2, t+1}^{i}}{S_{2, t}^{i}} \frac{P_{t}^{i}}{P_{t+1}^{i}}\right]
$$

where $\Psi_{E, t+1}^{i}(\bullet)$ is the function that describes how the external finance premium depends on the financial position of the entrepreneur and is given by: $\Psi_{E, t+1}^{i}(\cdot)=\left(\frac{N W_{t+1}^{i}}{q_{t}^{i} K_{t+1}^{i}}\right)^{-\gamma}$ with $\left(\Psi_{E, t+1}^{i}(\bullet)\right)^{\prime}<0, \Psi_{E}^{i}(1)=1$ and $\gamma$ is the elasticity of the external finance premium with respect to firm's leverage ratio. Thus, the external finance premium is an equilibrium inverse function of the aggregate financial position in the economy, expressed by the leverage ratio. Equation (24) provides the basis for the financial accelerator. If the entrepreneur's net worth goes up, the external finance premium falls, the cost of borrowing falls, and firms get cheaper access to credit.

The capital demand must satisfy the following differentiation between the ex post marginal return on capital, $E_{t}\left(R_{K, t+1}^{i}\right)$, and the marginal productivity of capital at $t+1, m p c_{t}^{i}$, which is the rental rate of capital:

$$
E_{t}\left(R_{K, t+1}^{i}\right)=E_{t}\left[\frac{m p c_{t+1}^{i}+(1-\delta) q_{t+1}^{i}}{q_{t}^{i}}\right]
$$

where $\delta$ is the capital depreciation rate and $(1-\delta) q_{t+1}^{i}$ is the value of one unit of capital used in $t+1$.

Aggregate entrepreneurial net worth accumulation of the economy depends on profits earned

9) For details, see Bernanke et al. (1999). 
in previous periods plus the bequest, $\Omega_{t}^{i}$, that newly entering entrepreneurs receive from entrepreneurs who leave the economy, and evolves according to:

$$
N W_{t+1}^{i}=\nu\left[R_{K, t}^{i} \dot{q}_{t-1}^{i} K_{t}^{i}-R_{w, t} \dot{\Psi}_{d, t}^{i}\left(d_{t}^{i}, Z_{t}^{i}\right) \frac{S_{2, t+1}^{i}}{S_{2, t}^{i}} \frac{P_{t}^{i}}{P_{t+1}^{i}}\left(\frac{N W_{t}^{i}}{q_{t-1}^{i} K_{t}^{i}}\right)^{-\gamma}\left(q_{t-1}^{i} K_{t}^{i}-N W_{t}^{i}\right)\right]+(1-\nu) \Omega_{t}^{i}
$$

\section{Capital producers}

Competitive capital producers use a linear technology to produce new capital $K_{t+1}^{i}$ from final investment goods $I_{t}^{i}$ and existing capital stock leasing from entrepreneurs without costs. When producing capital, they are subject to a quadratic capital adjustment cost specified as

$$
\frac{\psi_{I}}{2}\left(\frac{I_{t}^{i}}{K_{t}^{i}}-\delta\right)^{2} K_{t}^{i}
$$

where $\psi_{I}>0$ is the parameter that measures the adjustment cost elasticity.

The aggregate capital stock used by producers in each economy $i$ evolves as follow:

$$
K_{t+1}^{i}=\left[\frac{I_{t}^{i}}{K_{t}^{i}}-\frac{\psi_{I}}{2}\left(\frac{I_{t}^{i}}{K_{t}^{i}}-\delta\right)^{2}\right] K_{t}^{i}+(1-\delta) K_{t}^{i}
$$

Capital producers face an optimization problem which consists, in real terms, of choosing the level of investment that maximizes their profits:

$$
\max _{I_{t}^{i}}\left\{q_{t}^{i} I_{t}^{i}-I_{t}^{i}-\frac{\psi_{I}}{2}\left(\frac{I_{t}^{i}}{K_{t}^{i}}-\delta\right)^{2} K_{t}^{i}\right\}
$$

The following equilibrium condition holds:

$$
q_{t}^{i}-\psi_{I}\left(\frac{I_{t}^{i}}{K_{t}^{i}}-\delta\right)=1
$$

which is the standard Tobin's Q equation and links the price of capital to the marginal adjustment cost.

When $\psi_{I}=0$ (no adjustment costs), the capital price, $q_{t}^{i}$ is constant and equal to 1 . This shows that capital adjustment costs imply necessarily the capital price $\left(q_{t}^{i}\right)$ variation and therefore contribute to the volatility of entrepreneurial net worth. 


\section{Retailers: price and inflation dynamics}

The existence of retailers is the source of nominal stickiness in the economy. Retailers take wholesale goods as inputs, repackage these without cost, and sell them in a monopolistically competitive market. There are domestic goods retailers and imported goods retailers. Following Calvo (1983), we assume that retailers set nominal prices on a staggered basis: at each period, a fraction $\left(1-\phi^{i}\right)$ of retailers are randomly selected to set new prices while the remaining fraction $\phi^{i}$ of retailers keep their prices unchanged. For simplicity, these fractions are assumed to be equals within the two groups of retailers.

All home goods retailers purchase the wholesale goods from entrepreneurs at a price equal to the entrepreneurs' nominal marginal cost. Each retailer $j$ of them setting price at $t$ will choose the optimal price, $\widetilde{P}_{i, t}^{i}$, which maximizes the expected profits for $s$ periods, so that:

$$
\max _{\widetilde{P}_{i, t}^{i}(j)} E_{t}\left\{\sum_{s=0}^{\infty}\left(\beta \phi^{i}\right)^{s} \frac{\lambda_{t+s}^{i}}{\lambda_{t}^{i}}\left[Y_{i, t+s}^{i}(j)\left(\widetilde{P}_{i, t}^{i}(j)-P_{i, t+s}^{i} m c_{t+s}^{i}\right)\right]\right\}
$$

subject to the demand function,

$Y_{i, t+s}^{i}(j)=\left(\frac{\tilde{P}_{i, t+s}^{i}(j)}{P_{i, t+s}^{i}}\right)^{-\chi} Y_{i, t+s}^{i}$, where $\frac{\lambda_{t+s}^{i}}{\lambda_{t}^{i}}$ is the households' marginal utilities ratio between $t+s$ and $t$.

The first-order condition for this problem yields,

$$
\tilde{P}_{i, t}^{i}(j)=\frac{\chi}{\chi-1} \frac{E_{t}\left\{\sum_{s=0}^{\infty}\left(\beta \phi^{i}\right)^{s} \lambda_{t+s}^{i} Y_{i, t+s}^{i}(j) P_{i, t+s}^{i} m c_{t+s}^{i}\right\}}{E_{t}\left\{\Sigma_{s=0}^{\infty}\left(\beta \phi^{i}\right)^{s} \lambda_{t+s}^{i} Y_{i, t+s}^{i}(j)\right\}}
$$

Aggregating across all retailers, the price index for domestically produced goods is given by,

$$
P_{i, t}^{i}=\left[\left(1-\phi^{i}\right)\left(\tilde{P}_{i, t}^{i}\right)^{1-\chi}+\phi^{i}\left(P_{i, t-1}^{i}\right)^{1-\chi}\right]^{\frac{1}{1-\chi}}
$$

Combining log-linearized versions of equations (31) and (32) yields an expression of the inflation rate for domestically produced goods, defined by the following New Keynesian Phillips curve:

$$
\hat{\pi}_{i, t}^{i}=\beta E_{t} \hat{\pi}_{i, t+1}^{i}+\frac{\left(1-\phi^{i}\right)\left(1-\beta \phi^{i}\right)}{\phi^{i}} \widehat{m c}_{t}^{i}
$$


where $m c_{t}^{i}$ is the real marginal cost, $\pi_{i, t}^{i}=\left(\frac{P_{i, t}^{i}}{P_{i, t-1}^{i}}\right)$ is domestic inflation, and variables with hats are $\log$ deviations from their steady-state values.

Similarly, imported goods retailers purchase the products from foreign producers at the wholesale price, $P_{G, t}^{i}$. At the wholesale level, the law of one price holds. Thus, $P_{G, t}^{i}=S_{1, t}^{i} P_{k, t}^{k}$ and $P_{G, t}^{i}=S_{2, t}^{i} P_{w, t}^{w}$ are the wholesale prices (nominal marginal costs) for goods coming from the foreign country $k$ and the rest of the world (RoW), respectively. But at the retail level, we assume that the law of one price does not hold (such as $P_{k, t}^{i} \neq S_{1, t}^{i} P_{k, t}^{k}$ and $P_{w, t}^{i} \neq S_{2, t}^{i} P_{w, t}^{w}$ ). There is therefore incomplete exchange rate pass-through in the model. Similarly to the home good retailers, imported goods retailers set prices according to a Calvo-style price setting equation. Their optimization problems are identical except for the definition of the real marginal costs. The latter are, respectively, $\left(\frac{S_{1, t}^{i} P_{k, t}^{k}}{P_{k, t}^{i}}\right) \equiv L O P G_{k, t}^{i}$ and $\left(\frac{S_{2, t}^{i} P_{w, t}^{w}}{P_{w, t}^{i}}\right) \equiv L O P G_{w, t}^{i}$ for imported goods from the country $k$ and the RoW. The inflation rates for imported goods then satisfy these following New Keynesian Phillips curves:

$$
\begin{aligned}
& \hat{\pi}_{k, t}^{i}=\beta E_{t} \hat{\pi}_{k, t+1}^{i}+\frac{\left(1-\phi^{i}\right)\left(1-\beta \phi^{i}\right)}{\phi^{i}} \widehat{\operatorname{lop} g_{k, t}^{i}} \\
& \hat{\pi}_{w, t}^{i}=\beta E_{t} \hat{\pi}_{w, t+1}^{i}+\frac{\left(1-\phi^{i}\right)\left(1-\beta \phi^{i}\right)}{\phi^{i}} \widehat{\operatorname{opg}}_{w, t}^{i}
\end{aligned}
$$

where $\pi_{k, t}^{i}$ and $\pi_{w, t}^{i}$ are imported inflation prices from the country $k$ and the RoW.

Finally, from equation (8), the CPI inflation rate, $\hat{\pi}_{t}^{i}$, is a composite of domestic, country $k$ and world goods prices inflation, such that:

$$
\hat{\pi}_{t}^{i}=\left(1-a_{1}^{i}-a_{2}^{i}\right) \hat{\pi}_{i, t}^{i}+a_{1}^{i} \hat{\pi}_{k, t}^{i}+a_{2}^{i} \hat{\pi}_{w, t}^{i}
$$

\section{Monetary policy regimes}

\section{Independent managed floating policies}

We assume that the domestic and foreign countries independently managed their nominal effective exchange rates (NEERs). We follow Monacelli (2004) who shows that a positive coefficient on exchange rate variation in the policy rule can be used to model a managed floating exchange rate. Each country $i \in\{\mathrm{H}, \mathrm{RoR}\}$ has its monetary autonomy and the monetary authority practices the managed exchange rate regime according to the following augmented Taylor-type rule: 


$$
\log \left(\frac{R_{t}^{i}}{R^{i}}\right)=\beta_{0}^{i} \log \left(\frac{R_{t-1}^{i}}{R^{i}}\right)+\left(1-\beta_{0}^{i}\right) E_{t}\left[\beta_{1}^{i} \log \left(\frac{\pi_{t+1}^{i}}{\pi^{i}}\right)+\beta_{2}^{i} \log \left(\frac{Y_{t}^{i}}{Y^{i}}\right)+\beta_{3}^{i} \log \left(\frac{\Delta S_{t+1}^{i}}{\Delta S^{i}}\right)\right]+e_{r, t}
$$

avec $e_{r, t} \sim$ i.i.d. $\left(0, \sigma_{e_{r}}^{2}\right)$.

$R^{i}, \pi^{i}, Y^{i}$ and $\triangle S^{i}$ are the steady-state values of $R_{t}^{i}, \pi_{t}^{i}, Y_{t}^{i}$ and $\Delta S_{t}^{i} ; \beta_{1}^{i}, \beta_{2}^{i}$ et $\beta_{3}^{i}$ are the coefficients that measure central bank responses to expected inflation, output deviations and expected NEER variations $\left(\triangle S_{t}^{i}\right) .0<\beta_{0}^{i}<1$ is the interest rate smoothing parameter.

\section{Monetary Union}

We assume that if countries decide to form a monetary union, they will opt for a floating exchange rate. This means they have the same and unique nominal exchange rate with respect to the rest of the world while they give up their intra-regional bilateral nominal exchange rates. Moreover, under the assumption of the floating exchange rate regime for the currency union, the monetary rule is not supposed to target the common nominal exchange rate variations (see IMF (2019)). Therefore, the common central bank sets the nominal interest rate according to the following Taylor-type interest rate rule:

$$
\log \left(\frac{R_{t}}{R}\right)=\beta_{0} \log \left(\frac{R_{t-1}}{R}\right)+\left(1-\beta_{0}\right) E_{t}\left[\beta_{1} \log \left(\frac{\pi_{t+1}^{u m}}{\pi^{u m}}\right)+\beta_{2} \log \left(\frac{Y_{t}^{u m}}{Y^{u m}}\right)\right]+e_{r, t}
$$

with $e_{r, t} \sim$ i.i.d. $\left(0, \sigma_{e_{r}}^{2}\right)$.

$R, \pi^{u m}$ and $Y^{u m}$ are the steady-state values of $R_{t}, \pi_{t}^{u m}$ and $Y_{t}^{u m}$, that are, respectively, the nominal interest rate, the inflation rate, and the output of the union. The variables $\pi_{t}^{u m}$ and $Y_{t}^{u m}$ are the average values of inflation and output of the two equal-size countries:

$$
\pi_{t}^{u m}=\frac{1}{2}\left(\pi_{t}^{h}+\pi_{t}^{f}\right) \text { and } Y_{t}^{u m}=\frac{1}{2}\left(Y_{t}^{h}+Y_{t}^{f}\right)
$$

$\beta_{1}>1$ and $\beta_{2}<1$ are coefficients that measure central bank responses to expected inflation and output deviations. The parameter $0<\beta_{0}<1$ captures the degree of interest rate smoothing.

\section{E. Govemment}

In this model, we abstract from public debt and assume that the government finances its expenditures in purchases of aggregate public goods $G_{t}^{i}$ through lump-sum taxes, such that: 


$$
P_{t}^{i} G_{t}^{i}=\tau_{t}^{i}
$$

Public spending is fully exogenous and follows the autoregressive process:

$$
\log \left(G_{t}^{i}\right)=\rho_{g} \log \left(G_{t-1}^{i}\right)+e_{g, t}
$$

where $e_{g, t} \sim$ i.i.d. $\left(0, \sigma_{e_{g}}^{2}\right)$.

\section{F. General equilibrium conditions}

In equilibrium, the factor markets, the final goods market, and the balance of payments must clear in each country $i \in\{\mathrm{H}, \mathrm{RoR}\}$.

Equilibrium in factor markets requires:

$$
N_{t}^{i}=\int_{0}^{1} N_{t}^{i}(j) d j \text { and } K_{t}^{i}=\int_{0}^{1} K_{t}^{i}(j) d j
$$

Let $Y_{t}^{i} \equiv\left(\int_{0}^{1} Y_{t}^{i}(j)^{\frac{\chi-1}{\chi}} d_{j}\right)^{\frac{\chi}{\chi-1}}$ denote aggregate output. Thus, the goods market clearing condition satisfies:

$$
Y_{t}^{i}=C_{i, t}^{i}+I_{i, t}^{i}+G_{i, t}^{i}+E X_{t}^{i}
$$

where $E X_{t}^{i}=a_{1}^{i}\left(\frac{P_{i, t}^{i}}{S_{1, t}^{i} P_{t}^{k}}\right)^{-\theta} A B_{t}^{k}+a_{2}^{i}\left(\frac{P_{i, t}^{i}}{S_{2, t}^{i} P_{t}^{w}}\right)^{-\theta} A B_{t}^{w}$

The variable $E X_{t}^{i}$ represents total exports and $A B_{t}^{i}$ (with $\in\{k, w\}$ ) stands for absorption. $A B_{t}^{i}, A B_{t}^{k}$ and $A B_{t}^{w}$ are, respectively, absorption in the economy $i$, the country $k$ and in the RoW such that,

$$
\begin{aligned}
& A B_{t}^{i}=C_{t}^{i}+I_{t}^{i}+G_{t}^{i} \\
& A B_{t}^{k}=C_{t}^{k}+I_{t}^{k}+G_{t}^{k}
\end{aligned}
$$

and $A B_{t}^{w}$ is an exogenous process.

Therefore the domestic economy's aggregate resource constraint can be rewritten as: 


$$
Y_{t}^{i}=\left(\frac{P_{i, t}^{i}}{P_{t}^{i}}\right)^{-\theta}\left[\left(1-a_{1}^{i}-a_{2}^{i}\right) A B_{t}^{i}+a_{1}^{i}\left(\frac{1}{R E R_{k, t}^{i}}\right)^{-\theta} A B_{t}^{k}+a_{2}^{i}\left(\frac{1}{R E R_{w, t}^{i}}\right)^{-\theta} A B_{t}^{w}\right]
$$

The evolution of net foreign assets at the aggregate level can be expressed for each country as:

$$
S_{2, t}^{i} R_{w, t-1} \Psi_{d, t-1}^{i}\left(d_{t-1}^{i}, Z_{t-1}^{i}\right) D_{t-1}^{i}=S_{2, t}^{i} D_{t}^{i}+E X_{t}^{i}-\left(I M_{k, t}^{i}+I M_{w, t}^{i}\right)
$$

where $I M_{k, t}^{i}$ and $I M_{w, t}^{i}$ are imports of country $i$ originating from country $k$ and from the RoW, respectively.

The expression of the evolution of the total real net foreign asset position in terms of steady-state output is:

$$
R_{w, t-1} \Psi_{d, t-1}^{i} \frac{S_{2, t}^{i}}{\pi_{t}^{i} S_{2, t-1}^{i}} d_{t-1}^{i}=d_{t}^{i}+\frac{1}{Y}\left(\frac{P_{i, t}^{i}}{P_{t}^{i}} Y_{t}^{i}-C_{t}^{i}-I_{t}^{i}-G_{t}^{i}\right)
$$

$\forall i, k \in\{\mathrm{H}, \mathrm{RoR}\}$ and $i \neq k$.

\section{G. Rest of the world}

We assume that the rest of the world (RoW) is fully exogenous and its related variables follow an autoregressive process such that:

$$
\begin{aligned}
& \log \left(A B_{t}^{w}\right)=\rho_{A B w} \log \left(A B_{t-1}^{w}\right)+e_{A B w, t} \\
& \log \left(R_{w, t}\right)=\rho_{R w} \log \left(R_{w, t-1}\right)+e_{r w, t} \\
& \log \left(\pi_{w, t}\right)=\rho_{\pi w} \log \left(\pi_{w, t-1}\right)+e_{\pi w, t}
\end{aligned}
$$

where $\rho_{x} \in[0,1]$ with $x=A B w, R w$ and $\pi w$ are the coefficients of autoregressive process and $e_{x, t} \sim i . i . d\left(0, \sigma_{e_{x}}^{2}\right)$ are the associated exogenous shocks.

\section{Calibration of the Model and Simulations Results}

To perform the simulation study, the model is log-linearized around the steady state, calibrated, and solved numerically using Dynare (Adjemian et al. (2011)). 


\section{A. Calibration of the model}

The calibration of the model is summarized in Table 2 below. To simulate the model, we have picked the values of model parameters for each country $i \in\{\mathrm{H}, \mathrm{R} \circ \mathrm{R}\}$, from both ASEAN data and the literature on the Emerging Market Economies (EME).

We set the discount factor of patient households, $\beta$, at 0.99 in order to match the average annual real risk-free interest rate of $4 \%$. We consider that the inverse of the intertemporal elasticity of substitution of consumption, $\sigma$, is equal to 2 (as in Sangaré (2016) and Devereux et al. (2006)). Following Christiano et al. (1997), the inverse of the Frisch elasticity of labor supply, $\eta$, is equal to 1 . As in Cook (2004), the elasticity of substitution between domestic and imported goods is assumed to be 1.4. The Elasticity of the risk premium with respect to NFA position is 0.0007 provided by Schmitt-Grohé and Uribe (2003). As in Choi and Cook (2004), the share of capital in the domestic production $\alpha$ is 0.35 . Following Cook (2004), the depreciation rate of capital, $\delta$, is assumed to be 0.025 . The internal capital adjustment costs parameter, $\psi_{1}$, is assumed to be 0.25 , close to the value used by Devereux et al. (2006). The Calvo parameters for domestic and imported goods prices are assumed to be equal to 0.75 , as estimated for four Southeast Asian countries (Malaysia, Indonesia, Philippines, and Thailand) in Wong et al. (2014).

Following Devereux et al. (2006) and in accordance with estimates in Elekdag et al. (2006), we set the steady-state ratio of capital relative to net worth to 3 , consistent with a high financial leverage in emerging economies and with estimates. We follow Devereux et al. (2006) in choosing a steady state risk spread of 200 basis points and a steady-state mark-up of $10 \%$ so that $\frac{\chi}{\chi^{-1}}=1.1$.

The elasticity of the external finance premium with respect to firms' leverage ratio $(\gamma)$ is assumed to be 1. As in Gertler et al. (2007), the probability for entrepreneurs of leaving the economy is picked at 0.0272 .

The shares of imported goods from the foreign country (i.e., the rest of the region) and from the rest of the world are respectively approximated by the intra-ASEAN trade openness (0.13) and the extra-ASEAN openness (0.38) using the average data of the five founding members of the ASEAN from 2003-2019. The ratios of consumption to GDP and public spending to GDP are set respectively to 0.55 and 0.11 as from the average data of the ASEAN-5 members. Data are from ASEAN and the World Bank databases.

For the monetary rules, the smoothing parameter of the nominal interest rate is assumed to be 0.5 as from estimates in Wong et al. (2014). Following Gertler et al. (2007), the coefficients associated to inflation and output gap in the Taylor rule are respectively set to 2 and 0.8 . To be close to Elekdag et al. (2006), we pick 0.7 as the value of the coefficient associated to the effective exchange rate in the monetary policy rule. 
Table 2. Parameter Calibration

\begin{tabular}{|c|c|c|}
\hline Description & Parameter & Value \\
\hline \multicolumn{3}{|l|}{ Preferences } \\
\hline Subjective discount factor & $\beta$ & 0.99 \\
\hline Inverse of the Frisch elasticity of labor supply & $\eta$ & 1 \\
\hline Inverse intertemporal elasticity of substitution in consumption & $\sigma$ & 2 \\
\hline Share of imported goods from the rest of the region & $a_{1}^{i}$ & 0.13 \\
\hline Share of imported goods from the rest of the world & $a_{2}^{i}$ & 0.38 \\
\hline Elasticity of substitution between domestic and imported goods & $\theta$ & 1.4 \\
\hline Elasticity of the risk premium with respect to NFA position & $\psi_{d}^{i}$ & 0.0007 \\
\hline \multicolumn{3}{|l|}{ Technology } \\
\hline Capital contribution to production function & $\alpha$ & 0.35 \\
\hline Capital depreciation rate & $\delta$ & 0.025 \\
\hline Internal capital adjustment costs parameter & $\psi_{I}$ & 0.25 \\
\hline Probability of not adjusting prices & $\phi^{i}$ & 0.75 \\
\hline Steady-state mark-up & $1 /(\chi-1)$ & 0.1 \\
\hline \multicolumn{3}{|l|}{ Financial frictions parameters } \\
\hline Steady-state capital-net worth ratio & $K^{i} / N W^{i}$ & 3 \\
\hline Steady-state quarterly risk spread & $R_{K}^{i}-R^{i}$ & 0.02 \\
\hline Elasticity of the external finance premium with respect to firm's leverage ratio & $\gamma$ & 1 \\
\hline Entrepreneurs' probability of leaving the economy & $(1-\nu)$ & 0.0272 \\
\hline Consumption/GDP ratio & $C^{i} / Y^{i}$ & 0.55 \\
\hline Public expenditures/GDP ratio & $G^{i} / Y^{i}$ & 0.11 \\
\hline Smoothing coefficient in the monetary rule & $\beta_{0}^{i}$ & 0.5 \\
\hline Inflation stabilizing coefficient in the monetary rule & $\beta_{1}^{i}$ & 2 \\
\hline Output stabilizing coefficient in the monetary rule & $\beta_{2}^{i}$ & 0.8 \\
\hline NEER targeting coefficient in the monetary rule & $\beta_{3}^{i}$ & 0.7 \\
\hline \multicolumn{3}{|l|}{ Persistence parameter of considered shocks } \\
\hline Autocorrelation of technology shock & $\rho_{A}$ & 0.7 \\
\hline Autocorrelation of external demand shock & $\rho_{A B w}$ & 0.6 \\
\hline
\end{tabular}

\section{B. Comparison between the independent managed floating regime and the monetary union}

We perform a counterfactual analysis by comparing the macroeconomic and welfare performances of an independent managed floating regime to those of a currency union. Under the assumption that a monetary union has been set up among the ASEAN-5 members, we ask whether participating countries would be better or worse off in that union when demand and supply shocks occur compared to the situation where they would have had their own independent managed floating 
regimes. It is worth noting that we are not interested in analyzing whether the ASEAN countries satisfy the optimum currency area criteria or not, which would have implied the comparison of the dynamics of the two countries of the model, we rather compare the performances of a same country under two different monetary regimes (i.e., a monetary union and a managed floating regime).

Therefore, we first compare the dynamics of the main macroeconomic variables in response to supply and demand shocks under the two considered regimes. Afterwards, we undertake a comparative welfare analysis across regimes and finally, a robustness analysis shows how the similarity in exchange rate targeting policies drives the results.

\section{Dynamic responses of the main domestic variables to a supply shock}

Figure 1 displays the dynamics of the main domestic variables in response to a one-standard deviation positive productivity shock under the monetary union and the managed floating regime.

Figure 1. Effects of a positive productivity shock on the domestic country
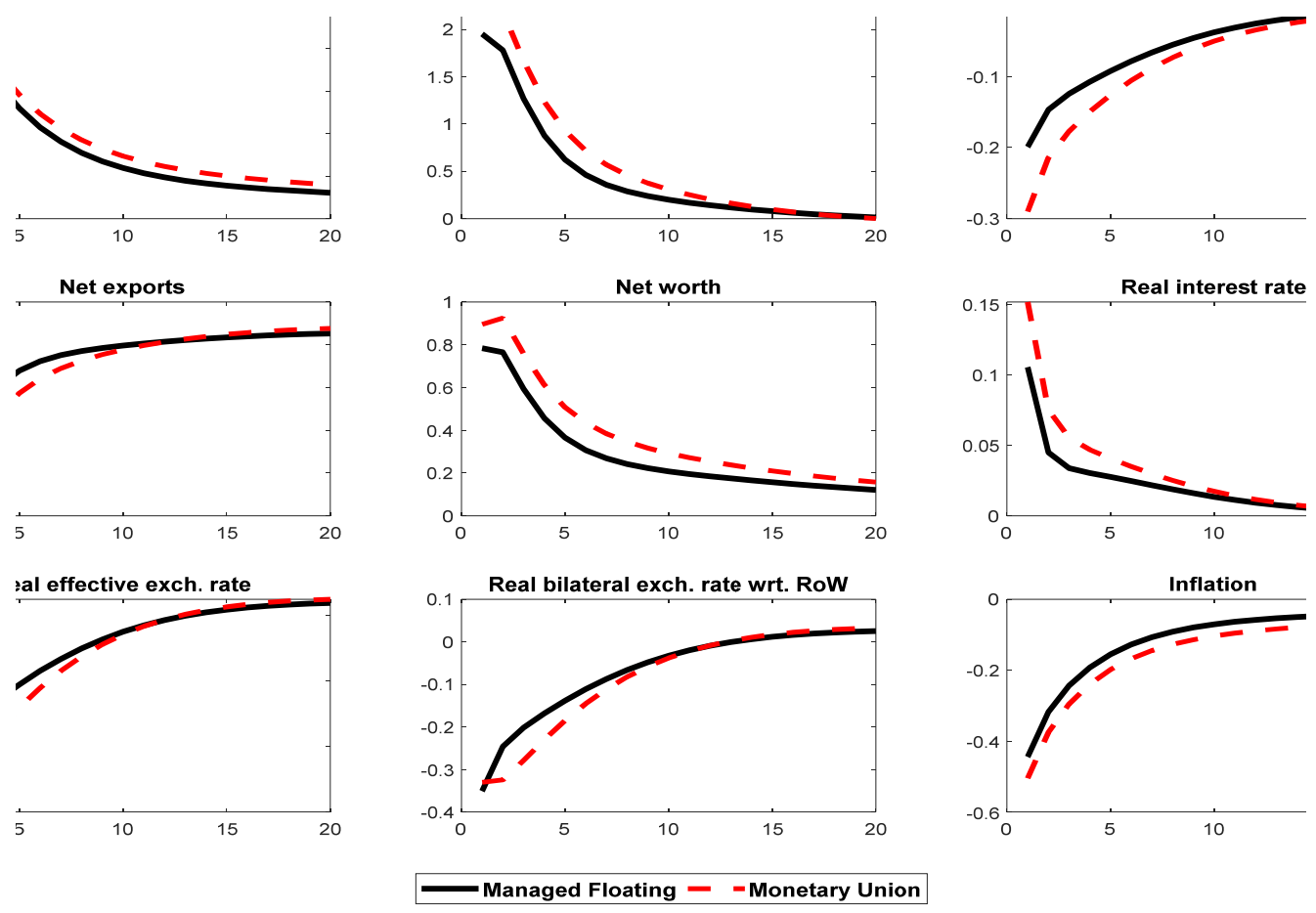

A persistent increase in factor productivity leads to an increase in investment and output. The hump-shaped pattern of output is due to the presence of the real and nominal rigidities in the model. This shock causes a decrease in marginal cost and inflation. Under both the 
monetary union and the managed floating regime, the central bank downwardly revises the nominal interest rates for stabilizing the expected inflation rates. However, this decline is less than the fall in inflation, leading to an increase in the real interest rates. As a result, private consumption declines and the real effective exchange rate (REER) and the real bilateral exchange rate (with respect to the rest of the world) appreciate. Changes in the REER are driven by the changes in the real bilateral exchange rate with respect to the rest of the world due to the symmetry of the shock. The REER appreciation reduces net exports. The appreciation of the real bilateral exchange rate with respect to the rest of the world increases the net worth (as the current value of the foreign currency denominated debt decreases) and the latter encourages investment. Moreover, the share of investment goods purchased abroad is cheaper in domestic currency, which in turn boosts investment. These effects amplify the initial rise of investment following the increase in productivity.

The responses of the monetary authorities to the shock create a slight but negligible difference between the two monetary regimes. Indeed, the monetary union's central bank does not react to changes in the NEER as it is assumed that if the countries decide to form a monetary union, they will opt for a floating exchange rate. When the productivity shock occurs, the appreciation pressure of the exchange rate leads the central bank to further reduce the nominal interest rate in the managed floating regime in addition to the downward trend related to the decrease in inflation, while the interest rate remains unchanged in the monetary union in the face of such pressure. Inflation decreases (and the real interest rate rises) more under the currency union than under the managed floating regime. The relative raise of the real interest rate under the monetary union compared to the managed floating regime leads to a higher decline in consumption under the former regime. Consequently, the REER and the real (bilateral) extra-regional exchange rate appreciate slightly more in the near-medium term under the monetary union than under the managed floating regime. This causes a relative increase in net worth, investment, and output under the monetary union. Finally, due to the opposite effects of the shock on consumption and net exports on the one hand and investment on the other, with almost the same differences across regimes, the responses of output are quantitatively and qualitatively similar under the two monetary regimes.

\section{Dynamic responses of the main domestic variables to an extemal demand shock}

In the context of foreign-currency denominated debt and a high degree of trade openness, it is relevant and useful to assess the choice of the exchange rate regime based on the external shocks, as they were the main transmission channels of both the global crisis and the 1997 Asian financial crisis to the ASEAN economies. In our simulation study, we therefore consider an external demand shock from the rest of the world (i.e., from the third countries).

Under the two monetary regimes (i.e., the monetary union and the managed floating regime), 
the dynamics of the domestic variables in response to a one-standard deviation decrease in exports to the rest of the world are depicted in Figure 2. This shock creates contractionary effects on both investment and output. Moreover, in response to contractionary effects of the shock, monetary authorities under both regimes decrease the nominal interest rate. Consequently, the inflation rates increase, and the real interest rates go down leading to the rise in consumption. According to the uncovered interest rate parity (UIP) condition, the real bilateral exchange rate (with respect to the rest of the world) and the REER depreciate. The real depreciation with respect to the rest of the world increases the cost of investment goods purchased abroad and decrease entrepreneurs' net worth (as the debt value increases in local currency). These developments increase the entrepreneurial risk premium and decline the entrepreneurial demand for borrowing, which is unfavorable to investment.

Figure 2. Effects of a negative external demand shock on the domestic country
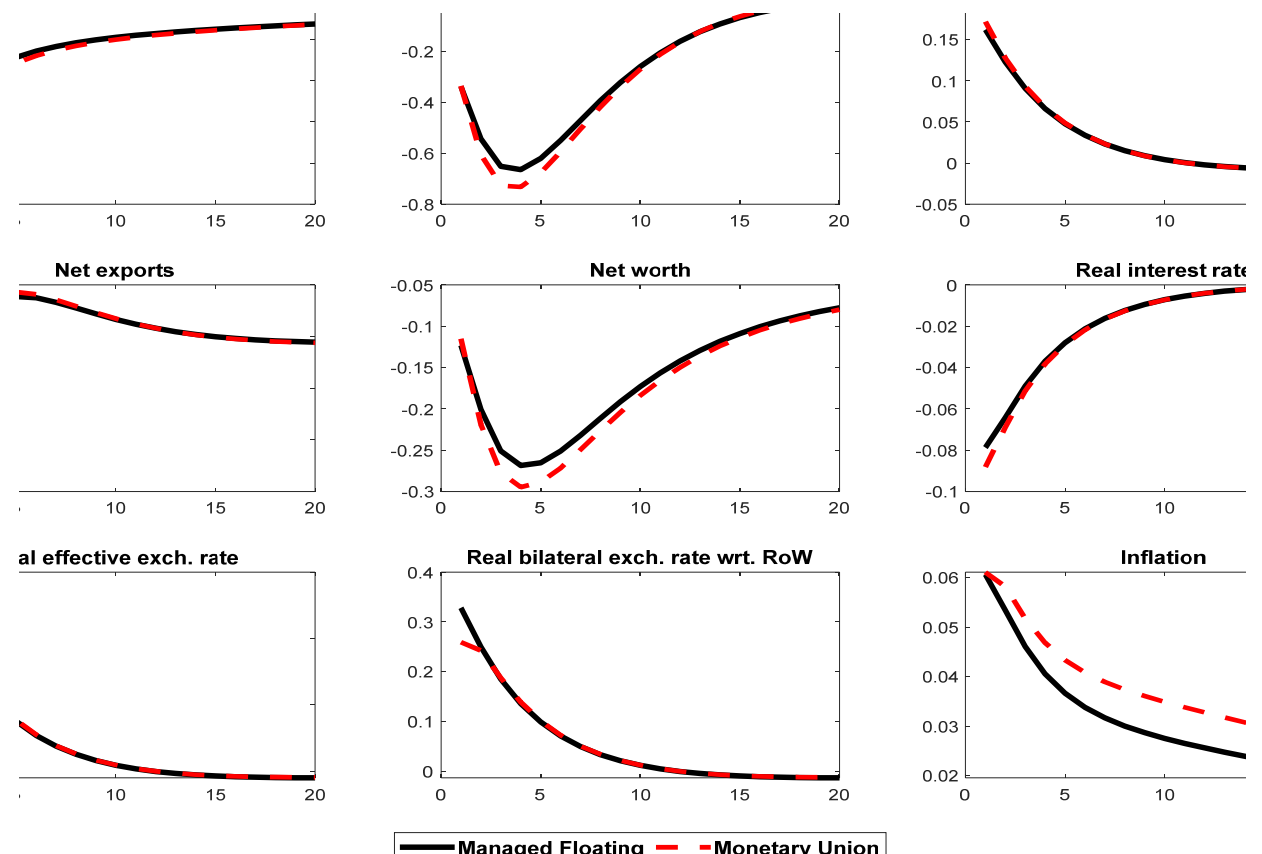

Managed Floating $-\quad-$ Monetary Union

Comparing the managed floating regime and the currency union shows comparable allocations under the two monetary regimes. Nevertheless, the negligible differences among regimes come from the response of the monetary authority under the managed floating regime. In particular, given the decrease in demand from the third countries and the low level of expected inflation, the nominal interest rate decreases slightly less under the managed floating regime than under the monetary union due to the expected nominal bilateral exchange rate depreciation under the former regime. Therefore, inflation increases slightly more under the monetary union than 
under the managed floating regime. As a result, the decrease of the real interest rate under the latter regime is limited at the impact of the shock compared to the monetary union. In addition, the real extra-regional and effective exchange rates are slightly more depreciated under the managed floating regime at the impact of the shock, as inflation is relatively low. Finally, net exports and output decrease slightly more at the impact of the shock under the currency union regime than under the managed floating regime. However, the difference across regimes is negligible due to the stability of the nominal bilateral exchange rates within the region.

\section{Welfare analysis}

We now compare the exchange rate arrangements based on the welfare gains and costs associated with different shocks. Following Lucas (1987), we use a welfare metric based on business cycles defined as the fraction of steady-state consumption that households would be willing to give up in order to negate the effect of the shocks. In other words, the welfare costs in terms of business cycles are given by the fraction of steady-state consumption that households would need, in the deterministic world (at the steady state) to yield the same welfare as would be achieved in the stochastic world (under the effect of the shock).

Formally: $U((1+u) C, N)=E\left(U\left(C_{t}, N_{t}\right)\right)$

$u$ represents the fraction of steady-state consumption given up due to the shock effect on the unconditional moments of consumption and worked hours. A negative value of $u$ means that households prefer the non-stochastic allocation and are willing to give up a percentage of consumption to get the same utility as under the effects of shocks (welfare cost), while a positive value means that they prefer the stochastic allocation compared to that of the steady state (welfare gain).

Table 3 shows the welfare costs of different regimes under the two considered shocks. The monetary union is slightly better in terms of welfare than the managed floating regime in the face of a domestic supply shock while the managed floating regime is slightly more desirable in the presence of external shocks such as an extra-regional demand shock. This is consistent with the findings from the impulse responses. The difference between the two monetary regimes in terms of welfare is negligible, suggesting that the independent managed floating regime would be able to replicate the welfare gains and costs of the monetary union. Therefore, for the ASEAN-5 members, keeping their own independent managed floating regime would have a comparable advantage in terms of welfare over forming a currency union in the wake of productivity and external demand shocks. This finding suggests that the choice of effective exchange rate targeting regimes for those countries would be a preferable way to move towards a currency union. 
Table 3. Welfare Costs (In Units of Steady-State Consumption) Across Different Monetary Regimes and Under Different Shocks

\begin{tabular}{ccc}
\hline Types of shocks & Monetary union & Managed floating \\
\hline Productivity shock & -0.28 & -0.29 \\
External demand shock & -0.12 & -0.1 \\
\hline
\end{tabular}

\section{Inspecting the role of coordination of exchange rate targeting policies}

Why does the independent managed floating regime produce comparable macroeconomic allocations and welfare costs to those of the currency union? Answering this question requires investigating the role of the similarity or coordination of the exchange rate targeting policy across countries. The results previously presented arise because of the stability of the intra-regional nominal exchange rates, which comes from the policy rule similarity among countries under the managed floating regime in the face of the shocks.

To assess the role of the similarity (i.e., coordination) of nominal effective exchange rate targeting across countries in driving the results from the analysis done so far, we perform a sensitivity analysis by introducing an asymmetry in the NEER targeting degree of policy rules under the independent managed floating regimes of countries.

In the two-country model framework, we assume that one of the two considered countries has a higher preference for stabilizing the NEER (and has chosen a higher value of $\beta_{3}^{i}$ ) compared to the other country, which picked a relatively low value of $\beta_{3}^{i}$. Note that $\beta_{3}^{i}$ denotes the preference coefficient for the NEER stabilization in the monetary policy rules when the countries are evolving under the independent managed floating regimes.

In our modeling framework and sensitivity exercise we assume that a group of ASEAN-5 countries (labeled by home country) chooses a higher parameter associated to the NEER in the Taylor rule compared to another group of countries whose preferences for the NEER stabilization are low. The difference between the two degrees of exchange rates targeting measures the asymmetry degree in managing the exchange rates. We call the 'low asymmetry' scenario that in which the difference between exchange rate targeting parameters across economies under the managed floating regime is low, and the 'high asymmetry' scenario which has a relatively high difference among exchange rate targeting coefficients in the Taylor rules. Therefore, we calibrate $\beta_{3}^{H}=0.7$ and $\beta_{3}^{R o R}=0.001$ for the high symmetry scenario and $\beta_{3}^{H}=0.7$ and $\beta_{3}^{R o R}=0.2$ for the low asymmetry scenario.

Figure 3 shows the effect of a symmetric and positive productivity shock on home and foreign (RoR) output and the nominal (bilateral) intra-regional exchange rate. The domestic nominal bilateral exchange rate depreciates as the foreign nominal interest rate decreases less than the domestic interest rate (via the UIP with the perfect capital mobility across countries). 
More specifically, the domestic monetary policy rules react more to the NEER appreciation pressure from the productivity shock than the foreign monetary policy rule. Figure 3 shows that the low asymmetry in targeting the NEER causes a weak depreciation of the nominal bilateral exchange rate, suggesting that the convergence of the degrees of exchange rates targeting would lead to the stability of the nominal bilateral exchange rate within the region. In particular, the less asymmetry, the more stable the bilateral exchange rate is.

The difference between the effects of high and low asymmetries on output from home and foreign (RoR) countries is plotted on the right-hand side of Figure 3. We define the 'asymmetry effect gap' as the difference between the effects of the shock on output under the high asymmetry scenario and the same effects under the low asymmetry scenario. The result indicates that a high asymmetry scenario is favorable to the home country compared to the foreign country in terms of output responses at the impact of the shock. However, this ranking tends to be reversed in the medium term where output responses to the shocks seem to be higher under a high symmetry scenario than under a low symmetry scenario (i.e., positive) for both countries, but they are much higher for the foreign country. This is explained by the fact that the domestic monetary policy reacts much more to the NEER appreciation stemming from the rise in productivity, which in turn negatively affects much more domestic net exports and output under the high asymmetry scenario.

Figure 3. Effects of positive productivity shock on domestic and foreign output and the nominal bilateral exchange rate under different degrees of asymmetry
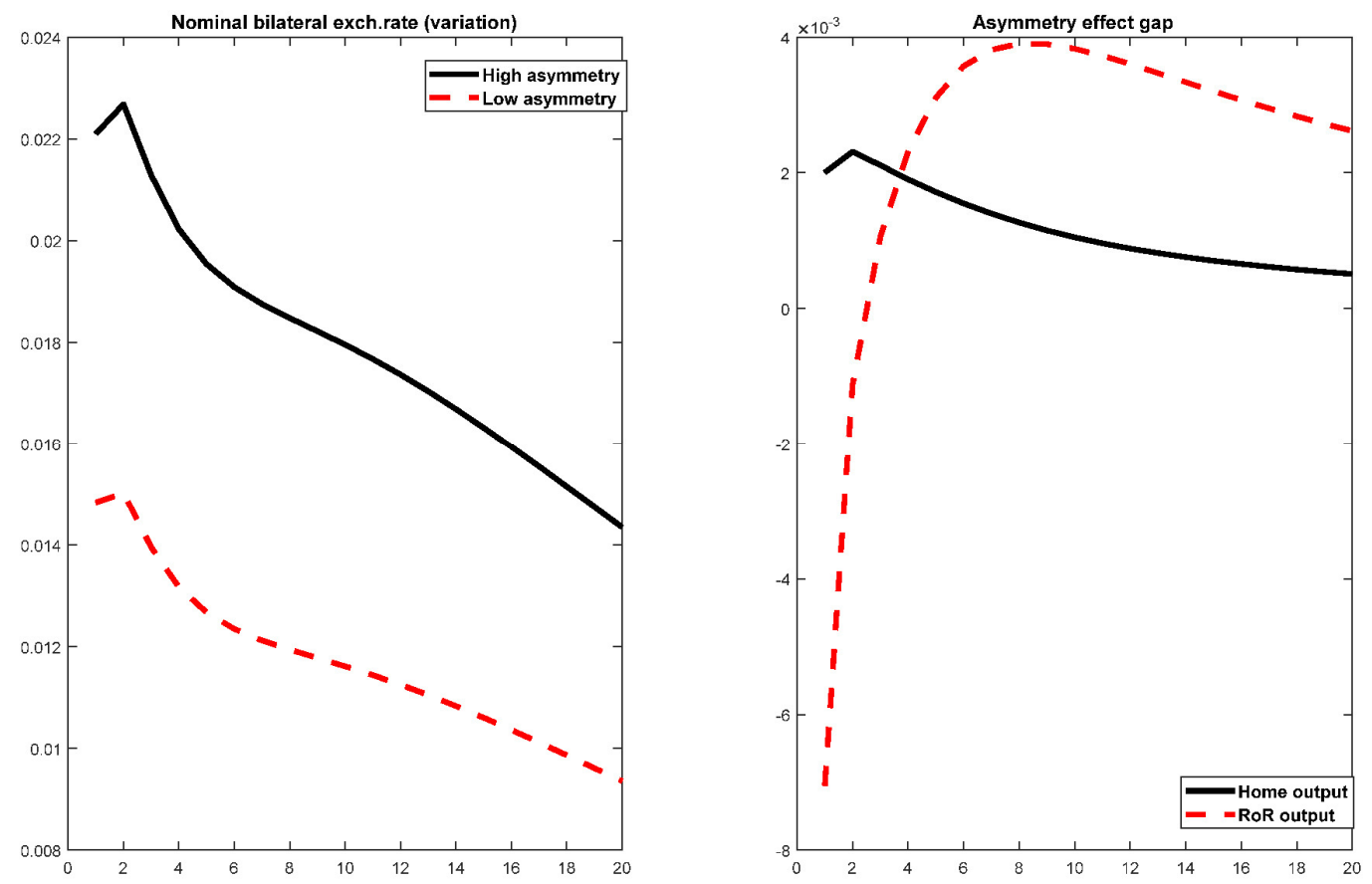
Figure 4 shows that when the difference between the NEER targeting coefficients across countries is reduced by $28.47 \%$, the volatility of the nominal (bilateral) intra-regional nominal exchange rate decreases by $34.67 \%$ in the face of a productivity shock. ${ }^{10)}$ This implies that the low asymmetry scenario stabilizes the nominal bilateral exchange rates within a region.

Figure 4. Volatility of the nominal (bilateral) intra-regional exchange rate under the productivity shock (in \%)

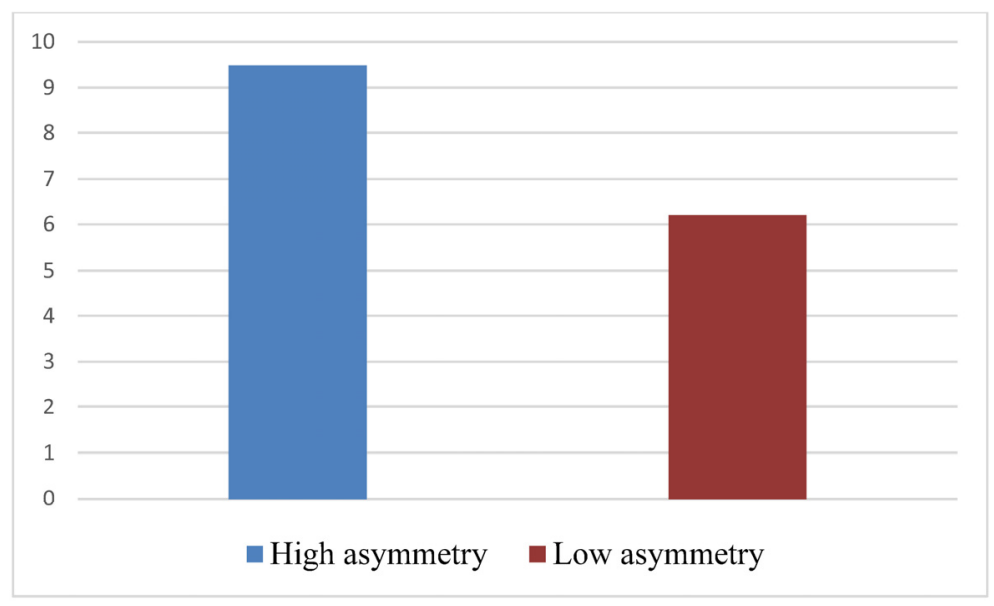

Figure 5 displays the effect of a symmetric and negative external demand shock on home and foreign output and the nominal bilateral exchange rate between the two countries. Following the shock, both monetary authorities cut the nominal interest rates. However, the nominal interest rate decreases more in the foreign country (RoR) than in the domestic country as the domestic authority should respond to the NEER expected depreciation, which tends to raise the nominal interest rate. This leads to the domestic nominal bilateral appreciation with respect to the foreign country. As before, the higher the difference between the NEER targeting coefficients is, the more important is the appreciation of the intra-regional nominal exchange rate. The gap between the effects of the external demand shock on domestic and foreign output under different degrees of asymmetry (i.e., asymmetry effect gap) is plotted on the right side of Figure 5. The interpretation is like what has previously been presented for the productivity shock.

According to Figure 6, a $28.47 \%$ reduction of the asymmetry among NEER targeting coefficients leads to a decrease of $33.57 \%$ in the volatility of the nominal regional exchange rate following an external demand shock.

10) The volatility is computed based on the simulation of 10000 periods. 
Figure 5. Effects of negative external demand shock on domestic and foreign output and on nominal bilateral exchange rate under different degrees of asymmetry
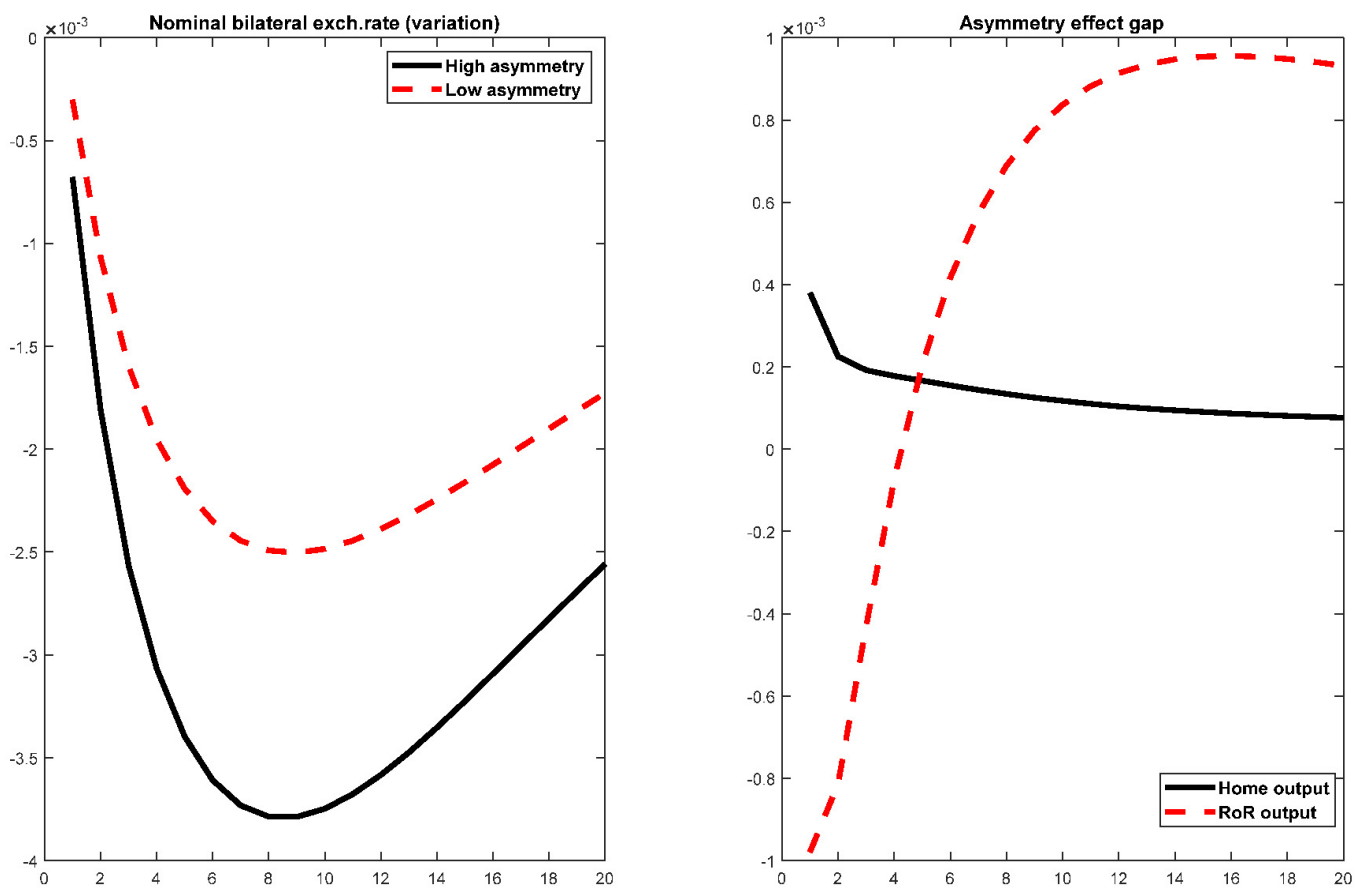

Figure 6. Volatility of the nominal (bilateral) intra-regional exchange rate under the external demand shock (in \%)

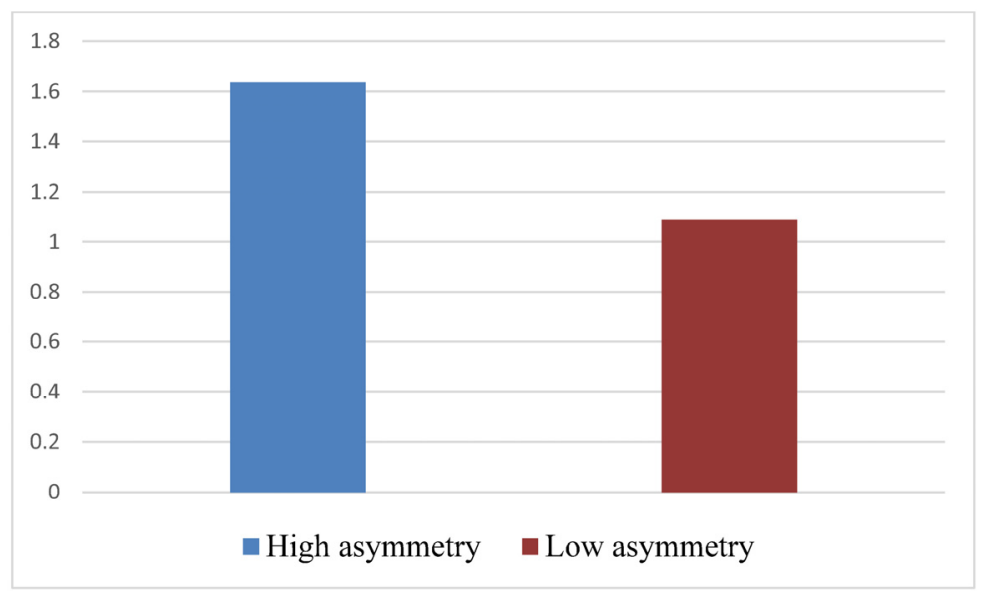

The degree of asymmetry in the NEER targeting affects output and the nominal bilateral exchange rate between the domestic and foreign countries. The less difference there is among authorities' preferences with respect to the NEER targeting, the more stabilized the nominal bilateral exchange rate between the two countries is. In the absence of asymmetry among policy 
coefficients (via policy coordination) of the managed floating regimes within a region, the stability of the nominal intra-regional exchange rates would arise so that the economies in the region would have comparable output and welfare effects as if they were participating in a currency area.

\section{Concluding Remarks}

This paper aims at performing a counterfactual analysis to determine whether the potential macroeconomic and welfare performances of a currency union are preferable or not to those from independent managed floating regimes in the ASEAN. To do this, we build a two open-country DSGE model that features nominal and real rigidities, incomplete exchange rate pass-through, financial frictions, and foreign currency denominated debt. We calibrate the model on the average data from the five founding members of the ASEAN and assess the performance of regimes under the effects of supply and demand shocks.

We find that the effects of these shocks on output and welfare under the independent managed floating regime are comparable to those under the currency union, suggesting the former can mimic the latter regime. We also find that this result is explained by the stability of the intra-regional nominal exchange rates arising from the similarity or cooperation of policy rules under the independent managed floating regimes. This suggests that the choice of exchange rate targeting regimes with comparable policy parameters for the ASEAN countries would be a preferable way to move towards a currency union. In particular, when the preferences in terms of NEER stabilization in the ASEAN region are close, there would be a stability of the nominal bilateral exchange rates within that region. The stability of the nominal bilateral exchange rates stems from the similarity of the nominal effective exchange rate targeting coefficients and the similarity of countries' trade-weighted baskets. This de facto stability of intra-regional exchange rates, arising either from coordinated or non-concerted policies, could produce similar macroeconomic allocations and welfare costs and gains as a currency area. These findings are in line with those from Engwerda et al. (2012), who find substantial gains from cooperation of ASEAN monetary authorities compared to forming a monetary union.

\section{References}

Adjemian, S., H. Bastani, M. Juillard, F. Karamé, F. Mihoubi, G. Perendia, J. Pfeifer, M. Ratto, \& S. Villemot. (2011). Dynare: Reference Manual, Version 4. Dynare Working Papers, 1. CEPREMAP. Balasubramaniam A., Puah C.-H., \& Abu Mansor, S. (2012). Economic Interdependence: Evidence from 
China and ASEAN-5 Countries. Modern Economy, 3, 122-125.

Basnet, Hem C., Sharma, Subhash C., \& Vatsa, P. (2015). Monetary policy synchronization in the ASEAN-5: an exchange rate perspective. Applied Economics, 47(1), 100-112.

Bayoumi, T., \& Mauro, P. (1999). The suitability of ASEAN for a regional currency arrangement. IMF Working paper, WP/99/ 162.

Bayoumi, T., Eichengreen, B., \& Mauro, P. (2000). On regional monetary arrangements for ASEAN. Journal of the Japanese and International Economies, 14, 121-148.

Bernanke, B. S., Gertler, M., \& Gilchrist, S. (1999). The financial accelerator in a quantitative business cycle framework. In J. Taylor, \& M. Woodford (Eds.), Handbook of Macroeconomics, vol. 2 (pp. 1341-1393). North-Holland, Amsterdam.

Binner, J., Chen, S-H., Lai, K-H., Mullineux, A., \& Swofford, J. L. (2011). Do the ASEAN countries and Taiwan form a common currency area? Journal of International Money and Finance, 30, 1429-1435.

Calvo, G. (1983). Staggered prices in a utility-maximizing framework. Journal of Monetary Economics, 12, 383-398.

Christensen, I., \& A. Dib. (2008). The financial accelerator in an estimated New-Keynesian model. Review of Economic Dynamics, 11, 155-78.

Christiano, L. J., Eichenbaum, M., \& Evans, C. L. (1997). Sticky price and limited participation models of money: a comparison. European Economic Review, 41, 1201-1249.

Choi, W. G., \& Cook, D. (2004). Liability dollarization and the bank channel. Journal of International Economics, 64(2), 247-75.

Cook, D. (2004). Monetary policy in emerging markets: Can liability dollarization explain contractionary devaluations? Journal of Monetary Economics, 51, 1155-1181.

Devereux, M. B., \& Engel, C. (2001). Monetary Policy in the Open Economy Revisited: Exchange Rate Flexibility and Price Setting Behavior. Mimeo.

Devereux, M. B., Lane, P., \& Xu, J. (2006). Exchange rates and monetary policy in emerging market economies. Economic Journal, 116, 478-506.

Eichengreen, B., \& Bayoumi, T. (1999). Is Asia an optimum currency area? In S. Collingen, J. Pisani-Perry, \& Y. Park (Eds.), Exchange Rate Policies in Emerging Asian Countries. London: Routledge.

Elekdag, S., Justiniano, A., \& Tchakarov, I. (2006). An estimated small open economy model of the financial accelerator. IMF Staff. Pap. 219-241.

Engwerda, J., Boldea, O., Michalak, T., Plasmans, J., \& Salmah. (2012). A simulation study of an ASEAN monetary union. Economic Modelling, 29, 1870-1890.

Gauchan, B., \& Sharin, V. (2018). Is South Asia an Optimum Currency Area? Journal of Economic Integration, 33, 3, September, 572-603.

Gertler, M., Gilchrist, S., \& Natalucci, F. M. (2007). External Constraints on Monetary Policy and the Financial Accelerator. Journal of Money, Credit and Banking, 39(2-3), 295-330.

IMF. (2006). Annual report on exchange arrangements and exchange restrictions. Washington, DC: IMF.

IMF. (2008). Annual report on exchange arrangements and exchange restrictions. Washington, DC: IMF.

IMF. (2019). Annual report on exchange arrangements and exchange restrictions. Washington, DC: IMF. 
Jean Louis R., Brown, R., \& Balli, F. (2011). On the feasibility of monetary union: Does it make sense to look for shocks symmetry across countries when none of the countries constitutes an optimum currency area? Economic Modelling, 28, 2701-2718.

Kenen, P. (1969). The theory of optimum currency areas: an eclectic view. In R. A. Mundell, \& A. K. Swoboda (Eds.), Monetary Problems of the International Economy (pp. 41-60). University of Chicago Press.

Lee, G. H. Y., \& Azali, M. (2012). Is East Asia an optimum currency area? Economic Modelling, 29, 87-95.

Lee, G. H. Y., \& Koh, S. G. M. (2012). The prospects of a monetary union in East Asia. Economic Modelling, 29, 96-102.

Lucas, R. (1987). Models of Business Cycle. Yrrjo Jahnsson Lectures Series, London: Blackwell.

McKinnon, R. (1963). Optimum currency areas. The American Economic Review, 53, 717-725.

Monacelli, T. (2004). Into the mussa puzzle: Momentary policy regimes and the real exchange rate in a small open economy. Journal of International Economics, 62, 191-217.

Mundell, A. R. (1961). A theory of optimum currency areas. The American Economic Review, 51(4), 657-665.

Nguyen T.-N.-A, Pham T.-H.-H., Vallé, T. (2016). Economic Integration in ASEAN+3: A Network Analysis. Journal of Economic Integration, 31(2), 275-325.

Ramayandi, A. (2005). ASEAN monetary cooperation: Issues and prospects. Pacific Economic Papers, 349.

Sangaré, I. (2016). External shocks and exchange rate regimes in Southeast Asia: A DSGE analysis. Economic Modelling, 58, 365-382.

Schmitt-Grohé, S., \& Uribe, M. (2003). Closing Small Open Economy Models. Journal of International Economics, 61, 163-185.

Sethapramote, Y. (2015). Synchronization of business cycles and economic policy linkages in ASEAN. Journal of Asian Economics, 39, 126-136.

Tan, M. S. (2016). Policy coordination among the ASEAN-5: A global VAR analysis. Journal of Asian Economics, 44, 20-40.

Wong, C.-Y., Eng, Y.-K., \& Habibullah, M. S. (2014). Rising China, anxious Asia? A Bayesian new Keynesian view. China Economic Review, 28, 90-106.

Zhang, Z., Sato, K., \& McAleer, M. (2004). Is a monetary union feasible for East Asia? Applied Economics, 36, 1031-1043. 